\title{
Bioactive compounds and antioxidant activity of jabuticaba var. Pingo de mel during its physiological development
}

\author{
Lismaíra Gonçalves Caixeta GARCIA ${ }^{1}$, Flávio Alves da SILVA ${ }^{2,3 *}$, Eduardo Ramirez ASQUIERI ${ }^{2,3}$, \\ Eduardo Valério de Barros Vilas BOAS ${ }^{3,4}$, Clarissa DAMIANI ${ }^{3,5}$ (D)
}

\begin{abstract}
The bioactive compounds and in vitro antioxidant activity of jabuticaba fruits var. Pingo de mel were evaluated during their physiological development. The fruits were harvested ten days after anthesis until maturity, at intervals of four days between collections. The period between anthesis and maturity was 34 days. Higher phenolics levels, hydrolysed tannins, and antioxidant activity were observed in 10 days after anthesis, while vitamin $C$ contents were higher throughout the ripening process. At the end of development (34 days), higher levels of vitamin $\mathrm{C}$ and lower hydrolysed tannin were observed. It is known that the lower the hydrolysed tannins, the better the sensory characteristics of the fruit, and considering the benefits of vitamin $\mathrm{C}$, it is necessary to harvest the jabuticaba fruits var. Pingo de mel in 34 days after anthesis for better use of these compounds.
\end{abstract}

Keywords: anthesis; Myrciaria sp.; vitamin C; hydrolysed tannins.

Practical Application: Monitoring the development of jabuticaba to determine the maximum levels of bioactive compounds.

\section{Introduction}

Jabuticaba is a non-climacteric, highly perishable fruit native to Brazil, and commonly named as brazilian grape tree, sabará, among others. The fruit is a black spherical berry with a thin and fragile peel, and whitish pulp that is slightly acidic and sweet, with an astringent taste. The composition and nutritional value of jabuticaba fruits and products are characterized by their high content of carbohydrates (mainly glucose and fructose), dietary fiber, minerals s, vitamins, and also other bioactive compounds (Alezandro et al., 2013a, b; Reynertson et al., 2008a; Wu et al., 2013a, b). The sweet taste and fruit acidity is probably due to the presence of sugars, organic acids and terpenes (Plagemann et al., 2012). In addition, several studies have shown significant antioxidant activity, anthocyanins (Einbond et al., 2004; Ascheri et al., 2006; Reynertson et al., 2008b), and high content of phenolic compounds in jaboticaba fruits.

Despite its great potential, there are no studies on the physiological development of jabuticaba var. Pingo de mel, which is widely cultivated in the Goias region. During fruit maturation, the bioactive compounds undergo a series of complex biosynthesis process, leading to the changes in their composition and content in plant and plant-derived foods (Prasanna et al., 2007).

Given the above, this study aimed to characterize the jabuticaba fruits var. Pingo de mel for their bioactive compounds and in vitro antioxidant activity along fruit development, targeting their health benefits.

\section{Materials and methods}

The experiment was performed from September to October 2014, at the Fazenda \& Vinícula Jabuticabal in New Fatima, district of Hidrolândia-GO (16 $55^{\circ} 32.35$ "S, and $\left.49^{\circ} 21^{\prime} 39.76^{\prime \prime} \mathrm{W}\right)$, $35.6 \mathrm{Km}$ from Goiânia-GO. The area provided for the experiment contained about 700 trees, and seventy trees of similar size and age ( 7 years) were selected at random, and the branches were marked on the occasion of the anthesis (flower opening) with wool yarn of different colors. The experiment was performed from September to October 2014, at the Fazenda \& Vinícula Jabuticabal in New Fatima, district of Hidrolândia-GO (16 55' 32.35 'S, and $\left.49^{\circ} 21^{\prime} 39.76^{\prime \prime} \mathrm{W}\right), 35.6 \mathrm{Km}$ from Goiânia-GO.

The fruits were collected in the morning and transported to the laboratory in polyvinyl chloride (PVC) plastic containers, in polystyrene boxes containing ice. For that, 800 fruits were harvested, representing the point 1 of analysis (10 DAA), 400 for the point 2 and 3 (14 and $18 \mathrm{DAA}$ ), and 200 fruits for the other points of analysis, divided into four equal lots, representing the replicates. Immediately after arriving at the laboratory, the fruits were selected for the presence of defects or plagues and washed in running water. On the day of harvest, extracts were extracted from the fruits for analysis of phenolic compounds, antioxidant activity in vitro, hydrolyzed tannins and vitamin $\mathrm{C}$. The extracts were then frozen at $-18^{\circ} \mathrm{C}$ until analysis.

${ }^{1}$ Programa de Pós-graduação em Administração - PPGA, Escola de Agronomia, Universidade Federal de Goiás - UFG, Goiânia, GO, Brasil

${ }^{2}$ Departamento de Ciência e Tecnologia de Alimentos, Universidade Estadual de Campinas - UNICAMP, Campinhas, SP, Brasil

${ }^{3}$ Universidade Federal de Goiás - UFG, Goiânia, GO, Brasil

${ }^{4}$ Universidade Federal de Lavras - UFLA, Lavras, MG, Brasil

${ }^{5}$ Departamento de Ciência dos Alimentos, Universidade Federal de Lavras - UFLA, Lavras, MG, Brasil

*Corresponding author: flaviocamp@gmail.com 


\subsection{Determinations}

\section{Physicochemical determinations}

To obtain the extracts, the samples (pulp and peel) were homogenized with ethyl ether in the ratio 1:20 (w/v) under stirring and protected from light for one hour. Subsequently, the extracts were filtered through Whatman filter paper \#1, and the volumes were adjusted. The extract was dried on filter paper for two hours at $35^{\circ} \mathrm{C}$ to evaporate the ethyl ether residue. Then, the residue was weighed into a beaker and ethanol was added in the ratio of 1:20, and the extraction process (stirring + filtration) was repeated. After filtration, the residue was kept on filter paper for 30 minutes at $50{ }^{\circ} \mathrm{C}$ to evaporate the residual solvent. Finally, water in the ratio of 1:20 was added to the residue from the previous extracts to obtain the aqueous extract, which was kept under stirring and protected from light for one hour. The extracts were stored in amber glass bottles at $-18{ }^{\circ} \mathrm{C}$ until completion of the analysis.

\section{Phenolic compounds}

Phenolic compounds were determined in the ether, ethanol and aqueous extracts in a spectrophotometer (Biospectro SP-220) at $750 \mathrm{~nm}$, using the Folin-Ciocalteau reagent (Waterhouse, 2002). The quantification was done using a standard curve of gallic acid, and the results were expressed as mg gallic acid equivalents (GAE) per $100 \mathrm{~g}$ sample.

\section{Antioxidante activity}

FRAP - Ferric Reducing Antioxidant Power

The antioxidant activity was determined in all extracts (ether, ethanol and aqueous) by the iron reduction method (FRAP - Ferric Reducing Antioxidant Power), according to Benzie \& Strain (1996) with modifications by Rufino et al. (2010). Readings (tripyridyl triazine ferrous complex) were measured in a spectrophotometer at $595 \mathrm{~nm}$ (Biospectro SP-220), and the results were expressed as $\mu \mathrm{mol} \mathrm{FeSO}_{4} \mathrm{~g}^{-1}$ of fresh weight.

\section{DPPH - 2,2-diphenyl-1-picrylhydrazyl}

The antioxidant activity was determined in the ether, ethanolic, and aqueous extracts by the DPPH method (2,2-diphenyl-1-picrylhydrazyl) according to Brand-Williams et al. (1995), with modifications by Borguini \& Torres (2009). The degree of discoloration of the DPPH radical at $517 \mathrm{~nm}$ was measured in spectrophotometer (Biospectro SP-220) with a concentration of $0.2 \mathrm{mg} \mathrm{mL}^{-1}$, and the results were expressed as \% discoloration. The absorbance readings were carried out after 20 minutes of reaction. The calculations were performed using the Equation 1:

$\%$ discoloration by DPPH $=\left[-1\left(\frac{\text { Abs sample }- \text { Abs blank }}{\text { Abs control }}\right)\right] * 100$

where Abs sample is the absorbance of the sample; Abs blank is the absorbance of the blank; and Abs control is the absorbance of control (750 $\mu \mathrm{L}$ methanol + $1.5 \mathrm{~mL} \mathrm{DPPH})$.
ABTS $^{+}$- 2,2 AZINO BIS (3-ethylbenzo thiazoline 6 sulfonic acid)

The antioxidant activity by the $\mathrm{ABTS}^{+}$radicals method was determined according to Miller et al. (1993) with modifications by Rufino et al. (2010) The absorbance was measured in a spectrophotometer (BiospectroSP-220) at $734 \mathrm{~nm}$ after 6 minutes of the addition of $\mathrm{ABTS}^{+}$. The results were expressed as $\mu \mathrm{mol}$ Trolox $\mathrm{g}^{-1}$ fresh weight.

\section{Hydrolysed tannins}

The content of hydrolysed tannins was measured in a spectrophotometer, according to Brune et al. (1991), with adaptations by Barcia et al. (2012). For tannins extraction, one $g$ sample was mixed with $50 \mathrm{~mL}$ methanol and stirred for $10 \mathrm{~min}$, followed by standing for one $\mathrm{h}$. After filtration, two $\mathrm{mL}$ extract were removed and eight mL FAS reagent (89\% of urea:ethyl acetate $1: 1 ; 10 \%$ of $1 \%$ gum arabic in deionized water; and $1 \%$ ferric ammonium sulfate of $5 \%$ in $\mathrm{HCl} 1 \mathrm{M}$ ) was added. After 15 min of reaction, readings were performed in a spectrophotometer (Biospectro SP-220) at $680 \mathrm{~nm}$ (blue), using methanol to reset the equipment (blank). The results were expressed as mg gallic acid equivalent per $100 \mathrm{~g}$ sample.

\section{Vitamin C}

The vitamin $\mathrm{C}$ content was extracted using of the procedure described by Abushita et al. (1997). Reading were performed in spectrophotometer (Biospectro SP-220), and the results were expressed as $\mathrm{mg}$ of ascorbic acid per $100 \mathrm{~g}$ sample.

\subsection{Statistical analysis}

The experiment was carried out using a completely randomized design (CRD) composed of seven maturation stages and three replicates, each replicate consisting of 60 fruits. The variables evaluated were subjected to a polynomial regression analysis as a function of the harvesting dates. The computer software SISVAR was used to fit the regression models by way of an $\mathrm{F}$ test at the 5\% probability level, to measure the significance of the proposed model.

\section{Results and discussion}

The stage of development of jabuticaba fruits var. Pingo de mel was 34 days, from anthesis to harvest, which represented the stages of growth, maturity and ripening. According to Donadio (2000), jaboticaba fruits ripen in about three weeks after flowering. However, this period can vary according to several factors, including species, climate, soil, temperature, and others. A significant difference $(\mathrm{p}<0.05)$ in the contents of bioactive compounds of jabuticaba fruits var. Pingo de mel was observed throughout the stage of development. The extraction process using solvents with different polarities allowed the extraction of phenolic compounds only in the ethanolic and aqueous extracts (Figure 1), once it was not possible to perform absorbance readings in the ether extract (data not shown). The content of phenolic compounds of the ethanolic extract of jabuticaba fruit decreased from the first harvest to 
14 DAA, from $279.15 \mathrm{mg}$ GAE $100 \mathrm{~g}^{-1}$ to $54.60 \mathrm{mg}$ of GAE $100 \mathrm{~g}^{-1}$. However, from $14 \mathrm{DAA}$ to full ripening of fruits, an increase was observed, with values of $98.87 \mathrm{mg}$ GAE $100 \mathrm{~g}^{-1}$ at 34 DAA. Alezandro et al. (2013a) evaluated the content of phenolic compounds of Sabará jaboticabas, and observed that the complete ripening led to a $67 \%$ decrease in the Folin-Ciocalteu reduction capacity in unripe berries.

Chitarra \& Chitarra (2005) have reported that young fruits contain a higher concentration of phenolics in tissues, and these compounds play important roles in plant, acting as a defense mechanism, reducing during the stages of development, which explains the higher content of phenolic compounds at 10 DAA. Taiz \& Zeiger (2006) have also pointed out an increase in the content of phenolic compounds during the fruit development, probably due to biotic and abiotic stresses that induces the secondary metabolism of the fruit.

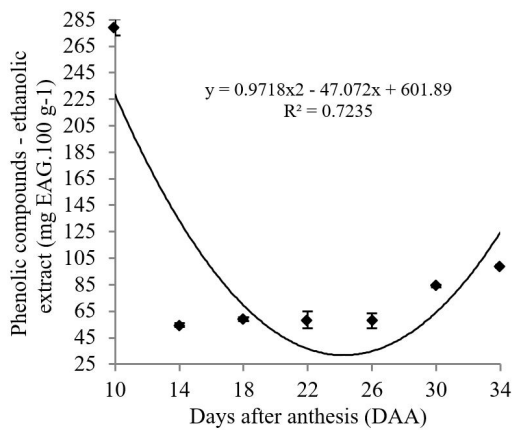

(a)
The content of phenolic compounds in the aqueous extract was higher (395.88 mg GAE $100 \mathrm{~g}^{-1}$ ) when compared to the ethanolic extract. Moreover, different behavior was observed for the phenolic compounds in the ethanolic extract, decreasing during development and ripening of the fruits, with a final value

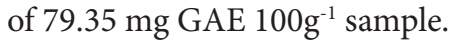

The differences observed for various solvents were also found by Pellegrini et al. (2007) and Melo et al. (2008), who reported that the solubility in a given solvent is a peculiar characteristic of the phytochemical, which explains the absence of a universal extraction due to the structural diversity and sensitivity of the phenolic compounds to extraction conditions.

Similar tendency was observed for the in vitro antioxidant activity in the different extracts determined by various methods (Figures 2, 3 and 4), once the highest contents of phenolic compounds were observed at 10 DAA.

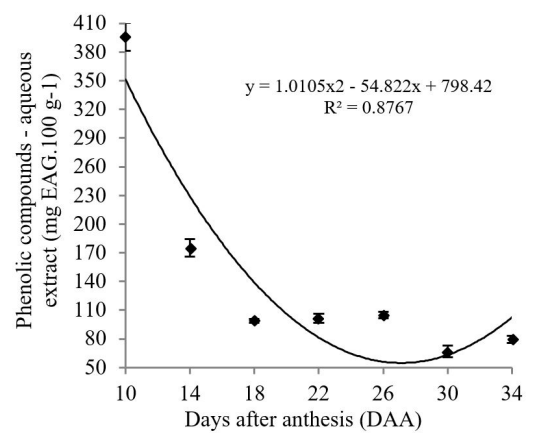

(b)

Figure 1. Mean values and standard deviation of phenolics content in ethanolic (a) and aqueous (b) extracts during the stages of development of jabuticaba fruits var. Pingo de mel.

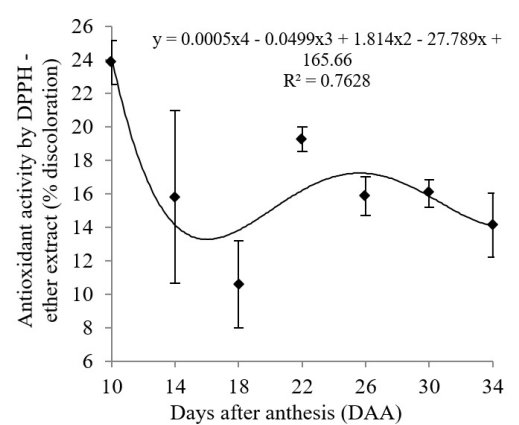

(a)

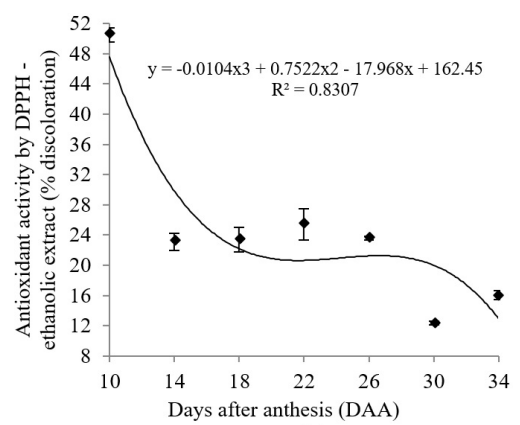

(b)

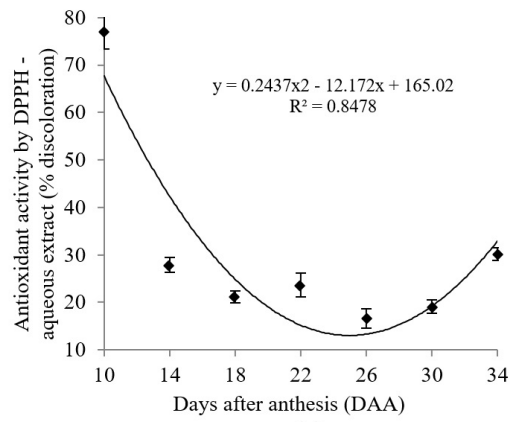

(c)

Figure 2. Mean values and standard deviation of the in vitro antioxidant activity by DPPH method in the ether (a) ethanolic (b), and aqueous (c) extracts during the stages of development of jabuticaba fruits var. Pingo de mel. 


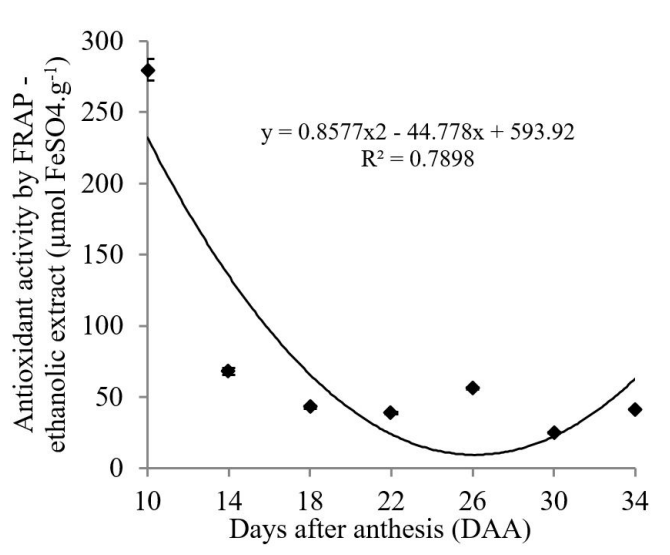

(a)

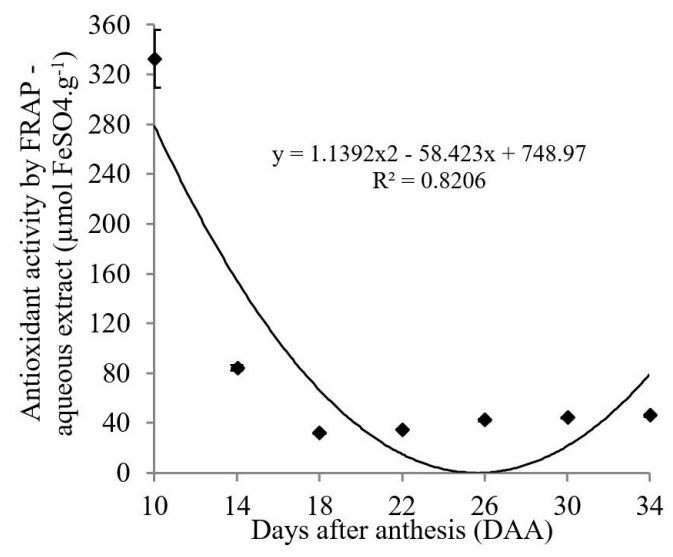

(b)

Figure 3. Mean values and standard deviation of in vitro antioxidant activity by FRAP method in ethanolic (a), and aqueous (b) extracts during the stages of development of jabuticaba fruits var. Pingo de mel.

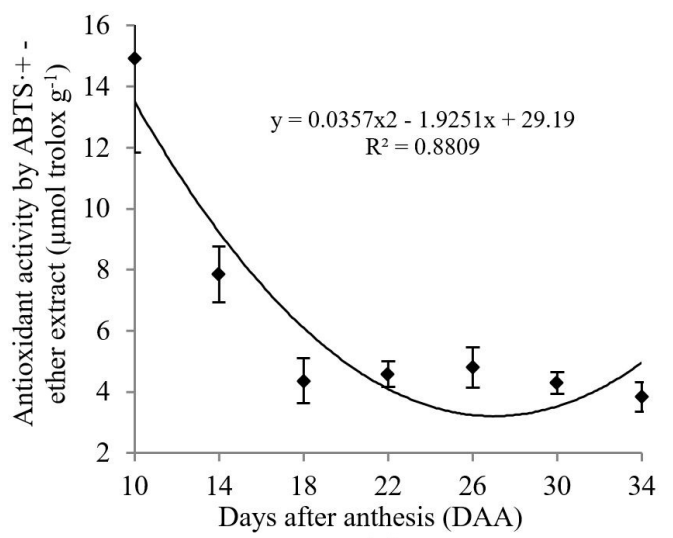

(a)

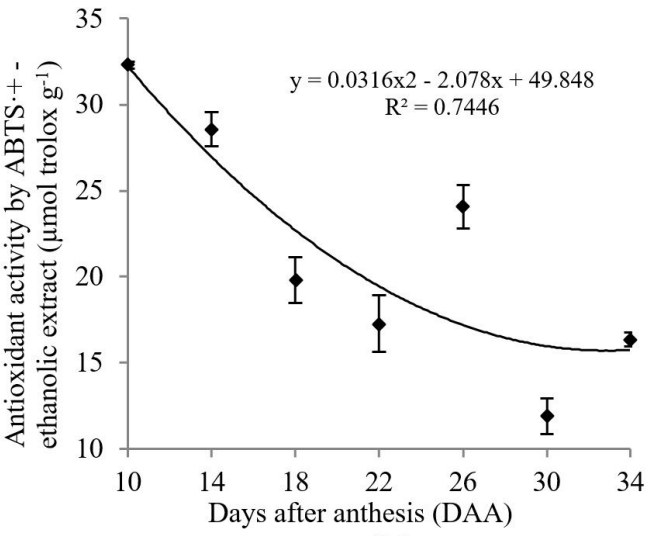

(b)

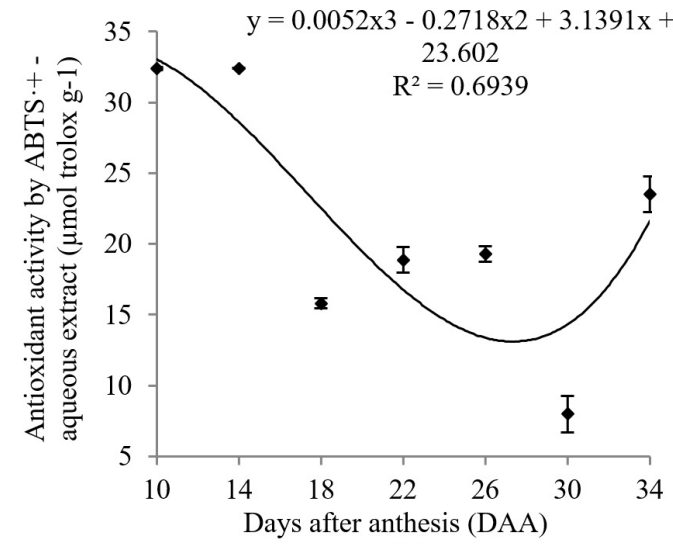

(c)

Figure 4. Mean values and standard deviation of the in vitro antioxidant activity by ABTS ${ }^{+}$method in the ether (a) ethanolic (b), and aqueous (c) extracts during the stages of development of jabuticaba fruits var. Pingo de mel.

A reduction in the antioxidant activity measured by the DPPH method (Figure 2) was observed until 18 DAA in the ether extract, increasing at $22 \mathrm{DAA}$, followed by a further reduction until ripening of the fruit, with $14 \%$ DPPH discoloration. In contrast, a decrease was observed in the ethanolic extract at 14 DAA, followed by stability up to $26 \mathrm{DAA}$, with a reduction at $30 \mathrm{DAA}$, and slight increase at $34 \mathrm{DAA}$, with $16 \% \mathrm{DPPH}$ discoloration.

The aqueous extract stood out when compared to the ether and ethanolic extracts, with higher values both in the initial stage of development as at the end of ripening, with almost double the discoloration percentage (30\% discoloration). Zozio et al. (2014) and Wang et al. (2016) used the DPPH method, and also 


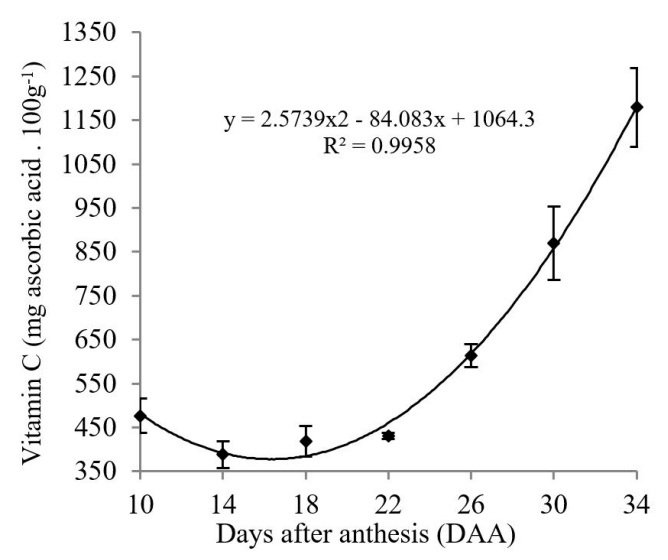

(a)

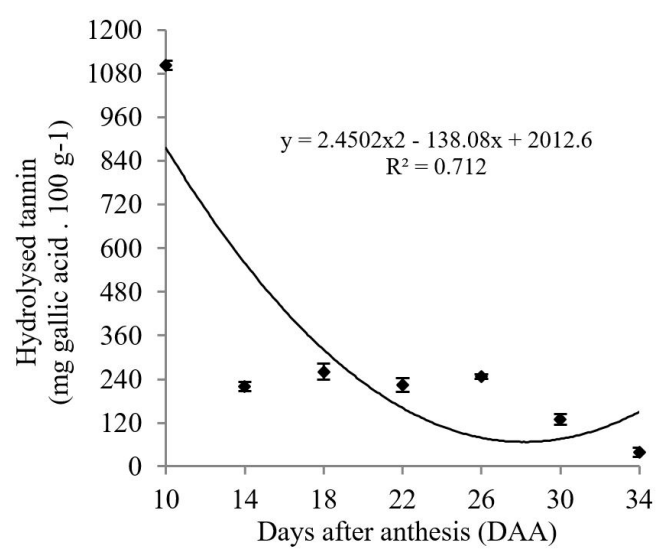

(b)

Figure 5. Mean values and standard deviation of the vitamin C content (a) and hydrolysed tannin (b) during the stages of development of jabuticaba fruits var. Pingo de mel.

observed a higher antioxidant activity in Ziziphus jujuba in the initial ripening periods.

As previously reported, it was not possible to quantify the antioxidant activity by FRAP method in the ether extract (data not shown), while the ethanolic and aqueous extracts showed similar behavior (Figure 3), with a peak at 10 DAA, reduction at $14 \mathrm{DAA}$, followed by a stability until fruit ripening, with final concentrations of $41.46 \mu \mathrm{mol} \mathrm{FeSO}_{4} \mathrm{~g}^{-1}$ and $45.84 \mu \mathrm{mol} \mathrm{Fe}_{2} \mathrm{SO}_{4} \mathrm{~g}^{-1}$, in the ethanolic and aqueous extracts, respectively. Rufino et al. (2010) analyzed the antioxidant activity of the aqueous extract of ripe jabuticaba fruit by FRAP method, and found higher values $\left(635 \pm 11.9 \mu \mathrm{mol} \mathrm{FeSO}_{4} \mathrm{~g}^{-1}\right)$ when compared with the results of the present study.

When evaluating the antioxidant activity by $\mathrm{ABTS}^{+}$method, the ether extract showed the lowest antioxidant activity when compared to the other extracts, while ethanolic and aqueous extracts showed similar results (Figure 4).

The ether extract showed a decrease of the antioxidant activity throughout the stages of development of jabuticaba fruits, with initial and final values of $14.91 \mu \mathrm{mol}$ trolox $\mathrm{g}^{-1}$ and $3.83 \mu \mathrm{mol}$ trolox $\mathrm{g}^{-1}$, respectively. Lower values were observed for the ethanolic extract up to $22 \mathrm{DAA}$, with subsequent increases and reductions until ripening, while the aqueous extract presented a low antioxidant activity at $14 \mathrm{DAA}$, with a tendency to stability up to $26 \mathrm{DAA}$, followed by a drop at $30 \mathrm{DAA}$, with new peak at 34 DAA.

Rufino et al. (2010) also investigated the antioxidant activity of the aqueous extract of ripe jabuticaba by the $\mathrm{ABTS}^{*+}$ method, and found higher values $\left(317 \mu \mathrm{mol}\right.$ trolox $\left.\mathrm{g}^{-1}\right)$ when compared with the results of the present study. Secondary metabolites are responsible for the antioxidant activity of fruits, and variations during the stages of development are related to the physiological maturation of fruits (Taiz \& Zeiger, 2006) or even in response to factors such as environmental stresses, which involve temperature, oxygen, and pathogens (Roussos et al., 2007).

Moreover, the difference in the extracts may be due to the extraction steps involving different solvents. Further studies on the appropriate solvent are necessary for selective extraction of natural antioxidants. In the present study, the various solvents provide maximum solubilization of the antioxidants in the sample. The use of three solvents with different polarities ethyl ether (2.9), ethanol (5.2), and distilled water (9) allowed the solubilization of more polar compounds (aqueous extract), with intermediate polarity (ethanolic extract), and nonpolar compounds (ether extract) (Borguini \& Torres, 2009).

With respect to the vitamin $C$ content (Figure $5 \mathrm{a}$ ), a slight reduction was observed up to $14 \mathrm{DAA}$, followed by elevation to full ripening of fruits, ranging from $476.21 \mathrm{mg}$ ascorbic acid $100 \mathrm{~g}^{-1}$ at DAA 10 to $1178.91 \mathrm{mg}$ ascorbic acid $100 \mathrm{~g}^{-1}$ at 34 DAA. These results indicate that the synthesis of ascorbic acid was higher during the beginning of ripening, as also observed by Neves et al. (2015) in Camu-Camu fruit. The degradation of cell wall polysaccharide possibly resulted in increased galactose, which is one of precursors of ascorbic acid biosynthesis (Wheeler et al., 1998; Smirnoff et al., 2001).

Rufino et al. (2010) studied the vitamin C content in mature jabuticabas and found lower values $\left(2.38 \mathrm{mg}\right.$ ascorbic acid $\left.100 \mathrm{~g}^{-1}\right)$ when compared to this study. This variation may be due to the ascorbic acid, besides influenced by the species, also suffers variations according to the plant genotype, maturation stage, soil and climatic conditions, since it has various functions in abiotic stress response (Ishikawa et al., 2006).

When compared the vitamin $\mathrm{C}$ levels of mature jabuticaba fruit var. Pingo de mel of the present study (1178.91 mg ascorbic acid $100 \mathrm{~g}^{-1}$ ) with the results found by Assis et al. (2001) and Rufino et al. (2010) in mature acerola (957 mg and $1357 \mathrm{mg}$ ascorbic acid $100 \mathrm{~g}^{-1}$, respectively), it can be stated that the jabuticaba is a source of this vitamin, as it contains vitamin C levels close to those of acerola, which is recognized as a fruit rich in vitamin $\mathrm{C}$.

The hydrolysed tannin contents of jabuticaba fruits var. Pingo de mel (Figure 5b) were $1103.76 \mathrm{mg}$ gallic acid $100 \mathrm{~g}^{-1}$ at $10 \mathrm{DAA}$ and $247.22 \mathrm{mg}$ gallic acid $100 \mathrm{~g}^{-1}$ at the end of ripening. A marked decrease in the levels of hydrolysed tannins was observed from 
10 DAA to 14 DAA, followed by a tendency to stabilization, since a higher astringency was observed in the initial period of fruit development. Robichaud \& Noble (1990) argue that tannins are compounds responsible for fruit astringency, but with more recent and detailed studies Tavares et al. (2016) suggest that hydrolysable tannins may be the main phenolic compounds responsible for the reported astringency. The disappearance of astringency is probably due to the condensation of the tannins, rendering them insoluble (condensed) and therefore incapable of forming complexes.

\section{Conclusion}

Jabuticaba fruit var. Pingo de mel exhibited high antioxidant activity and higher phenolic compounds levels in the green stage (10 DAA), though it was unfit for consumption and industrialization. Considering that the lower the hydrolised tannins, the better the fruit sensory quality, in addition to the health benefits of vitamin $\mathrm{C}$ and antioxidant activity, jabuticaba fruit harvesting should take place in 34 days after anthesis for better use of compounds.

\section{Acknowledgements}

The authors are grateful to FAPEG (Research Foundation of the State of Goías, Brazil) for the concession of a scholarship to Lismaíra Gonçalves Caixeta Garcia and the Farm and Winery Jabuticabal for donating the fruits used in the research.

\section{References}

Abushita, A. A., Hebshi, E. A., Daood, H. G., \& Biacs, P. A. (1997). Determination of antioxidant vitamins in tomatoes. Food Chemistry, 60(2), 207-212. http://dx.doi.org/10.1016/S0308-8146(96)00321-4.

Alezandro, M. R., Dubé, P., Desjardins, Y., Lajolo, F. M., \& Genovese, M. I. (2013a). Comparative study of chemical and phenolic compositions of two species of jaboticaba: Myrciaria jaboticaba (Vell.) Berg and Myrciaria cauliflora (Mart.) O. Berg. Food Research International, 54(1), 468-477. http://dx.doi.org/10.1016/j.foodres.2013.07.018.

Alezandro, M. R., Granato, D., \& Genovese, M. I. (2013b). Jaboticaba (Myrciaria jaboticaba (Vell.) Berg), a Brazilian grape-like fruit, improves plasma lipid profile in streptozotocin-mediated oxidative stress in diabetic rats. Food Research International, 54(1), 650-659. http://dx.doi.org/10.1016/j.foodres.2013.07.041.

Ascheri, D. P. R., Ascheri, J. L. R., \& Carvalho, C. W. P. (2006). Caracterização da farinha de bagaço de jabuticaba e propriedades funcionais dos extrusados. Food Science and Technology (Campinas), 26(4), 897-905. http://dx.doi.org/10.1590/S0101-20612006000400029.

Assis, S. A., Lima, D. C., \& Oliveira, O. M. M. F. (2001). Activity of pectinmethylesterase, pectin content and vitamin $\mathrm{C}$ in acerola fruit at various stages of fruit development. Food Chemistry, 74(2), 133137. http://dx.doi.org/10.1016/S0308-8146(01)00104-2.

Barcia, M. T., Pertuzatti, P. B., Jacques, A. C., Godoy, H. T., \& Zambiazi, R. (2012). Bioactive compounds, antioxidant activity and percent composition of jambolão fruits (Syzygium cumini). The Natural Products Journal, 2(2), 129-138. http://dx.doi.org/10.2174/22103 15511202020129.

Benzie, I. F. F., \& Strain, J. J. (1996). The ferric reducing ability of plasma (FRAP) as a measure of antioxidant power: The FRAP assay.
Analytical Biochemistry, 239(1), 70-76. http://dx.doi.org/10.1006/ abio.1996.0292. PMid:8660627.

Borguini, R. G., \& Torres, E. F. S. (2009). Tomatoes and tomato products as dietary sources of antioxidants. Food Reviews International, 25(4), 313-325. http://dx.doi.org/10.1080/87559120903155859.

Brand-Williams, W., Cuvelier, M. E., \& Berser, C. (1995). Use of a free radical method to evaluate antioxidant activity. LebensmittelWissenschaft + Technologie, 28(1), 25-30. http://dx.doi.org/10.1016/ S0023-6438(95)80008-5.

Brune, M., Hallberg, L., \& Skanberg, A. (1991). Determination of ironbinding phenolic groups in foods. Journal of Food Science, 56(1), 128-131. http://dx.doi.org/10.1111/j.1365-2621.1991.tb07992.x.

Chitarra, M. I., \& Chitarra, A. B. (2005). Pós-colheita de frutos e hortaliças: fisiologia e manuseio (2. ed). Lavras: UFLA.

Donadio, L. C. (2000). Jabuticaba (Myrciaria jaboticaba (Vell) Berg) (55 p.). Jaboticabal: FUNEP.

Einbond, L. S., Reynertson, K. A., Luo, X., Basile, M. J., \& Kennelly, E. J. (2004). Anthocyanin antioxidants from edible fruits. Food Chemistry, 84(1), 23-28. http://dx.doi.org/10.1016/S0308-8146(03)00162-6.

Ishikawa, T., Dowdle, J., \& Smirnoff, N. (2006). Progress in manipulating ascorbic acid biosynthesis and accumulation in plants. Physiologia Plantarum, 126(3), 343-355. http://dx.doi.org/10.1111/j.13993054.2006.00640.x.

Melo, E. A., Maciel, M. I. S., Lima, V. L. A. G., \& Nascimento, R. J. (2008). Antioxidant capacity of the fruits. Brazilian Journal of Pharmaceutical Sciences, 44(2), 193-201.

Miller, N. J., Rice-Evans, C., Davies, M. J., Gopinathan, V., \& Milner, A. (1993). A novel method for measuring antioxidant capacity and its application to monitoring the antioxidant status in premature neonates. Clinical Science, 84(4), 407-412. http://dx.doi.org/10.1042/ cs0840407. PMid:8482045.

Neves, L. C., Silva, V. X., Chagas, E. A., Lima, C. G. B., \& Roberto, S. R. (2015). Determining the harvest time of camu-camu [Myrciaria dubia (H.B.K.) McVaugh] using measured pre-harvest atributes. Scientia Horticulturae, 186, 15-23. http://dx.doi.org/10.1016/j. scienta.2015.02.006.

Pellegrini, N., Colombi, B., Salvatore, S., Brenna, O. V., Galaverna, G., Del Rio, D., Bianchi, M., Bennett, R. N., \& Brighenti, F. (2007). Evaluation of antioxidant capacity of some fruit and vegetable foods: efficiency of extraction of a sequence of solvents. Journal of the Science of Food and Agriculture, 87(1), 103-111. http://dx.doi. org/10.1002/jsfa.2682.

Plagemann, I., Krings, I., Berger, R. G., \& Maróstica Jr., M. R. (2012). Volatile constituentsof jabuticaba (Myrciaria jaboticaba (Vell.) O. Berg) fruits. The Journal of Essential Oil Research, 24(1), 45-51. http://dx.doi.org/10.1080/10412905.2012.645651.

Prasanna, V., Prabha, T. N., \& Tharanathan, R. N. (2007). Fruit ripening phenomena-na overview. Critical Reviews in Food Science and Nutrition, 47(1), 1-19. http://dx.doi.org/10.1080/10408390600976841. PMid:17364693.

Reynertson, K. A., Basile, M. J., \& Kennelly, E. J. (2008a). Antioxidant potential of seven myrtaceous fruits. Ethnobotany Research and Applications, 3, 25-36. http://dx.doi.org/10.17348/era.3.0.25-36.

Reynertson, K. A., Yang, H., Jiang, B., Basile, M. J., \& Kennelly, E. J. (2008b). Quantitative analysis of antiradical phenolic constituents from fourteen edible Myrtaceae fruits. Food Chemistry, 109(4), 883-890. http://dx.doi.org/10.1016/j.foodchem.2008.01.021. PMid:21340048.

Robichaud, J. L., \& Noble, A. C. (1990). Astringency and bitterness of selected phenolics in wine. Journal of the Science of Food and Agriculture, 53(3), 343-353. http://dx.doi.org/10.1002/jsfa.2740530307. 
Roussos, P. A., Matsoukis, A., Pontikis, C. A., \& Chronopoulou-Sereli, A. (2007). Relations of environmental factors with the phenol content and oxidative enzyme activities of olive explants. Scientia Horticulturae, 113(1), 100-102. http://dx.doi.org/10.1016/j.scienta.2007.01.017.

Rufino, M. S. M., Alves, R. E., Brito, E. S., Pérez-Jiménez, J., SauraCalixto, F., \& Mancini-Filho, J. (2010). Bioactive compunds and antioxidante capacities of 18 non-traditional tropical fruits from Brazil. Food Chemistry, 121(4), 996-1002. http://dx.doi.org/10.1016/j. foodchem.2010.01.037.

Smirnoff, N., Conklin, P., \& Loewus, F. A. (2001). Biosynthesis of ascorbic acid in plants: a renaissance. Annual Review of Plant Physiology and Plant Molecular Biology, 52(1), 437-467. http://dx.doi.org/10.1146/ annurev.arplant.52.1.437. PMid:11337405.

Taiz, L., \& Zeiger, E. (2006). Plant physiology (4. ed). Sunderland: Sinauer Associates.

Tavares, I. M. C., Lago-Vanzela, E. S., Rebello, L. P. G., Ramos, A. M., Gómez-Alonso, S., García-Romero, E., Da-Silva, R., \& HermosínGutiérrez, I. (2016). Comprehensive study of the phenolic composition of the edible parts of jambolan fruit (Syzygium cumini (L.) Skeels). Food Research International, 82, 1-13. http://dx.doi.org/10.1016/j. foodres.2016.01.014.

Wang, B., Huang, Q., Venkitasamy, C., Chai, H., Gao, H., Cheng, N., Cao, W., Lv, X., \& Pan, Z. (2016). Changes in phenolic compounds and their antioxidant capacities in jujube (Ziziphus jujuba Miller) during three edible maturity stages. Lebensmittel-Wissenschaft + Technologie, 66, 56-62. http://dx.doi.org/10.1016/j.lwt.2015.10.005.

Waterhouse, A. L. (2002). Polyphenolics: determination of total phenolics. In R. E. Wrolstad (Ed.), Current protocols in food analytical chemistry. New York: John Wiley \& Sons.

Wheeler, G. L., Jones, M. A., \& Smirnoff, N. (1998). The biosynthetic pathway of vitamin C in higher plants. Nature, 393(6683), 365-369. http://dx.doi.org/10.1038/30728. PMid:9620799.

Wu, S. B., Long, C., \& Kennelly, E. J. (2013a). Phytochemistry and health benefits of jaboticaba, an emerging fruit crop from Brazil. Food Research International, 54(1), 148-159. http://dx.doi.org/10.1016/j. foodres.2013.06.021.

Wu, S. B., Wu, J., Yin, Z., Zhang, J., Long, C., Kennelly, E. J., \& Zheng, S. (2013b). Bioactive and marker compounds from two edible darkcolored Myrciaria fruits and the synthesis of jaboticabin. Journal of Agricultural and Food Chemistry, 61(17), 4035-4043. http://dx.doi. org/10.1021/jf400487g. PMid:23597039.

Zozio, S., Servent, A., Cazal, G., Mbéguié-A-Mbéguié, D., Ravion, S., Pallet, D., \& Abel, H. (2014). Changes in antioxidant activity during the ripening of jujube (Ziziphus mauritiana Lamk). Food Chemistry, 150, 448-456. http://dx.doi.org/10.1016/j.foodchem.2013.11.022. PMid:24360474. 